University of Nebraska - Lincoln

DigitalCommons@University of Nebraska - Lincoln

Sociology Department, Faculty Publications

Sociology, Department of

Summer 1987

\title{
Women Sociologists in the Midwest: A Status Update
}

\author{
Mary Ann Lamanna \\ University of Nebraska at Omaha \\ Baila Miller \\ University of Illinois at Chicago \\ Helen A. Moore \\ University of Nebraska-Lincoln, hmoore1@unl.edu
}

Follow this and additional works at: https://digitalcommons.unl.edu/sociologyfacpub

Part of the Sociology Commons

Lamanna, Mary Ann; Miller, Baila; and Moore, Helen A., "Women Sociologists in the Midwest: A Status Update" (1987). Sociology Department, Faculty Publications. 111.

https://digitalcommons.unl.edu/sociologyfacpub/111

This Article is brought to you for free and open access by the Sociology, Department of at DigitalCommons@University of Nebraska - Lincoln. It has been accepted for inclusion in Sociology Department, Faculty Publications by an authorized administrator of DigitalCommons@University of Nebraska - Lincoln. 


\title{
Women Sociologists in the Midwest: A Status Update
}

\author{
Mary Ann Lamanna \\ University of Nebraska at Omaha \\ Baila Miller \\ University of Illinois at Chicago \\ Helen Moore \\ University of Nebraska-Lincoln
}

Corresponding author - Mary Ann Lamanna, Department of Sociology and Anthropology, University of Nebraska at Omaha, Omaha, Nebraska 68182.

\begin{abstract}
In this article, an earlier study of the status of academic women sociologists in the Midwest that was extended to 1984-1985 is discussed. Type of appointment, rank, and chairpersons, as well as position in a Ph.D. rather than an M.A. program were used in the study as indicators of employment status. Midwest Sociological Society (MSS) leadership positions and participation in the annual MSS meeting served as indicators of professional participation. The results show that gains in employment status for women slowed in the 1980s. Employment of women in sociology department positions, especially in full-time positions and higher ranks, continued to lag behind the proportion of women Ph.D.s in the field. Women were overrepresented in the secondary labor market of part-time employment. However, women are now almost as likely to be employed in Ph.D. as well as M.A. programs. While gains in employment status generally slowed, professional participation has accelerated in recent years. Possible explanations for the differential penetrability of the two realms are offered. The appropriateness of statistical parity as a standard for evaluating equality in academic employment also is discussed. This article proposes that structural barriers to employment equity for women may not be more significant than direct discrimination.
\end{abstract}

Are women sociologists better off in the 1980s - after more than a decade of concern about the status of women in the profession? Has retrenchment in higher education in the last decade had an impact on the status of women?

To assess the current status of academic women sociologists in the Midwest, ${ }^{1}$ we extended an earlier study (Thompson et al. 1980) to $1984-1985 .^{2}$ Data on type of appoint- 
ment, rank, and chair positions were used as indicators of employment status. Professional participation was measured by leadership positions in the Midwest Socio- logical Society and participation in MSS annual meetings. Data were obtained from the ASA Guide to Graduate Departments, Directory of Departments, and from MSS annual meeting programs.

Use of ASA and MSS publications as data sources has certain advantages that contribute to the reliability and validity of an ongoing status assessment. Annual data are routinely available and monitoring can be continued with some uniformity by a changing cadre of interested sociologists. The reporting rate of graduate programs appears to be $100 \%$, and the undergraduate departmental response is also high.

Published lists and programs have their limits. They do not give individual career histories, nor do they provide information about departmental hiring, promotion decisions, or the selection process for MSS positions. Also, reliance on ASA and MSS published sources limits employment data to sociology departments, excluding women sociologists in other university units or applied positions. All but the chair data are drawn from graduate departments.

While reliance on data from sociology departments with graduate programs is primarily pragmatic, one can argue that integration of women into what are considered (rightly or wrongly) the most prestigious academic positions is a crucial measure of women's status in the profession. Whatever their limitations, these data serve as rough indicators of trends in women's employment status and professional participation over the last decade and a half.

What do these data tell us about equality? Interpretation of our data generates the same controversies that have arisen in other occupations and, indeed, in the courts (e.g., Equal Opportunity Commission v. Sears, Roebuck, and Co., 1986; Johnson v. Transportation Agency, Santa Clara County, California, 1987). Interpretive issues are themselves part of the debate about what constitutes equality for women and minorities. In our analysis we assume that equal status is attained when the distribution of women and men on status indicators is proportionate to their relative numbers in the field. This is the standard that triggers special affirmative action review of hiring within a university department (Hess 1984). Several appeals courts have accepted this conceptualization of the "underutilization" of women faculty (Lindgren et al. 1984, citing Smith v. University of North Carolina, 1980, and Lynn v. Regents of the University of California, 1981; see also Szafran 1984), and the Supreme Court seems now to have committed itself to this standard (Johnson v. Transportation Agency of Santa Clara County, 1987).

\section{Employment Status}

Tables 1, 2, and 3 present data on the type, program level, and rank of faculty appointments held by women in Midwest graduate departments from 1969 to $1985 .{ }^{3}$ During this period women made dramatic gains, increasing their share of academic positions from just under $12 \%$ in 1969 to $22 \%$ in 1985 (Table 1).

Progress slowed for women in the 1980s, with only a slight percentage gain from 1979 to 1985 . The absolute number of positions held by women has remained at about the same level since 1977. Women continue to hold a smaller share of academic positions than would be predicted from their 27\% share of Ph.D.s in 1981 (American Sociological Association 1984). ${ }^{4}$ 
Table 1. Women in Midwest Graduate Departments of Sociology by Type of Appointment, 1969 to $1985^{*}$

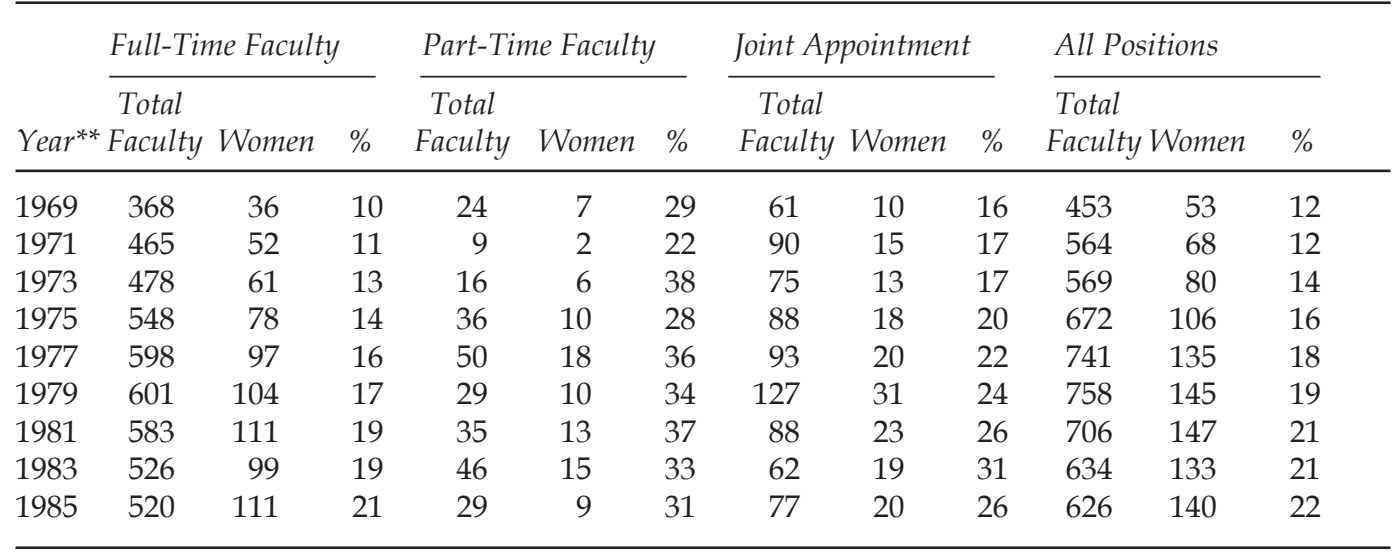

* For each year the sex of one or more faculty members was undeterminable, and thus these persons were not included in the analysis. The numbers omitted for each year are: 1969, 1; 1971,9; 1973,2; 1975,9; 1977,$9 ; 1979,7 ; 1981,30 ; 1983,17 ; 1985,8$. Visiting and adjunct professors were also omitted except as part-time teaching faculty.

** In previous years emeriti were included; they were a negligible proportion of the total. In 1985 there were 33 emeriti listed as full-time and 5 as part-time; all were omitted so that totals and percentages will more accurately reflect faculty lines.

\section{Type of Appointment}

Table I indicates the numbers and percentages of women in full-time, joint, and parttime academic appointments. Women's share of full-time sociology positions almost doubled during the 1970s and has increased slightly in the 1980s. But women are not yet employed in full-time sociology positions proportionately to their share of Ph.D.'s.

We consider joint appointments equivalent to full-time sociology department positions in status and privilege. Women made substantial gains in proportionate share of joint positions, holding $31 \%$ in 1983 . This strong representation of women occurred despite considerable fluctuation that returned the absolute number of joint positions in 1983 to more or less what it was in 1969. In 1985 the number of positions increased, but women's share fell back to $26 \%$.

Gender composition of part-time faculty employment shows a year-to-year fluctuation that undoubtedly reflects program changes, as well as the use of part-time instructors as a reserve labor force. Women in 1985, as throughout the period, were more likely than men to be in the marginal part-time positions. This consistency is surprising. One would expect a decline in the proportion of women part-time faculty in recent years (1) if women have increased opportunity for tenure-track positions; (2) if partners are gender-free in their couple decisions so that more men are now available for part-time work as the geographically immobile, jobless spouses of employed women; and/or (3) early retirement programs provide part-time status for senior professors, who are more likely to be male. Despite a slight decline, women in sociology, as in other disciplines (Griffin and Griffin 1985; Rohter 1987) continue to be overrepresented in part-time work. ${ }^{5}$

Other observers share our perception that academic labor markets are segmenting into a privileged class of tenured and tenure-track professors and a growing disadvantaged 
class of part-time and temporary workers (Abel 1984). We have some concern about the fact that women are overrepresented in part-time positions by $41 \%$ (using their share of all positions as a standard). In the 1980s (1981-1985) women were almost twice as likely $(9 \%)$ as men (5\%) to be employed part-time. Hartung (1985) found gender to be the strongest predictor of secondary labor market placement in her research in four midwestern states.

\section{M.A. and Ph.D. Programs}

Women held 23\% of faculty positions in Ph.D. programs in 1985 and are now only slightly less likely to be employed in Ph.D. than in M.A. programs (Table 2). This is a considerable gain in the status of women since 1969, when women were almost three times as likely (23\%) to be employed in M.A. programs as in Ph.D. programs (8\%).

As with academic employment generally, women are proportionately less apt to be employed full-time in Ph.D. programs than they are to have part-time or joint appointments, but this is one arena where women have continued to gain. Women hold $22 \%$ of full-time positions in Ph.D. programs, exactly the same as their overall employment percentage, although less than their $27 \%$ share of Ph.D. degrees.

Table 2. Women Employed in Ph.D. and M.A. Institutions by Type of Appointment, 1969, 1979, 1983,1985

\begin{tabular}{|c|c|c|c|c|c|c|}
\hline & \multicolumn{3}{|c|}{ Ph.D. Institutions } & \multicolumn{3}{|c|}{ M.A. Institutions } \\
\hline & Women & $\%$ & $\begin{array}{c}\text { Total } \\
\text { Faculty }\end{array}$ & Women & $\%$ & $\begin{array}{c}\text { Total } \\
\text { Faculty }\end{array}$ \\
\hline \multicolumn{7}{|l|}{1969} \\
\hline Full-time & 16 & 6 & 273 & 20 & 21 & 95 \\
\hline Joint appointment & 8 & 16 & 49 & 2 & 17 & 12 \\
\hline Part-time & 2 & 17 & 12 & 5 & 42 & 12 \\
\hline Total & 26 & 8 & 334 & 27 & 23 & 119 \\
\hline \multicolumn{7}{|l|}{1979} \\
\hline Full-time & 56 & 15 & 363 & 48 & 20 & 238 \\
\hline Joint appointment & 23 & 24 & 96 & 8 & 26 & 31 \\
\hline Part-time & 7 & 39 & 18 & 3 & 27 & 11 \\
\hline Total & 86 & 18 & 477 & 59 & 21 & 280 \\
\hline \multicolumn{7}{|l|}{1983} \\
\hline Full-time & 64 & 18 & 356 & 34 & 20 & 170 \\
\hline Joint appointment & 13 & 30 & 44 & 6 & 33 & 18 \\
\hline Part-time & 11 & 33 & 34 & 4 & 33 & 12 \\
\hline Total & 88 & 20 & 434 & 44 & 22 & 200 \\
\hline \multicolumn{7}{|l|}{1985} \\
\hline Full-time & 69 & 22 & 320 & 42 & 21 & 200 \\
\hline Joint appointment & 16 & 27 & 60 & 4 & 24 & 17 \\
\hline Part-time & 6 & 27 & 22 & 3 & 43 & 7 \\
\hline Total & 91 & 23 & 402 & 49 & 22 & 224 \\
\hline
\end{tabular}


Table 3. Rank of Women in Full-Time Faculty Positions: 1969, 1979, 1983, and 1985*

\begin{tabular}{|c|c|c|c|c|c|c|c|c|c|c|c|c|}
\hline \multirow[b]{2}{*}{ Position } & \multicolumn{3}{|c|}{1969} & \multicolumn{3}{|c|}{1979} & \multicolumn{3}{|c|}{1983} & \multicolumn{3}{|c|}{1985} \\
\hline & $\begin{array}{c}\text { Total } \\
\text { Faculty }\end{array}$ & Women & $\%$ & $\begin{array}{l}\text { Total } \\
\text { Faculty }\end{array}$ & Women & & $\begin{array}{l}\text { Total } \\
\text { Faculty }\end{array}$ & Women & $\%$ & $\begin{array}{c}\text { Total } \\
\text { Faculty }\end{array}$ & Women & $\%$ \\
\hline Professor & 128 & 6 & 5 & 205 & 18 & 9 & 217 & 26 & 12 & 206 & 24 & 12 \\
\hline Associate professor & 79 & 7 & 9 & 185 & 29 & 16 & 170 & 33 & 19 & 176 & 35 & 20 \\
\hline Assistant professor & 110 & 11 & 10 & 196 & 52 & 27 & 122 & 36 & 30 & 134 & 51 & 38 \\
\hline Instructor-lecturer & 38 & 9 & 24 & 13 & 3 & 23 & 4 & 2 & 50 & 4 & 1 & 25 \\
\hline All faculty & 355 & 33 & 9 & 599 & 102 & 17 & 513 & 97 & 19 & 520 & 111 & 21 \\
\hline
\end{tabular}

* Differences in the numbers in this and earlier tables are due to the lack of information on rank in some cases, and on omission of Professors Emeriti and research faculty from the rank calculations.

\section{Rank}

Striking gender differences in rank exist among full-time faculty in sociology departments (Table 3). Descending in rank, one finds an increasing proportion of women: in $1985,12 \%$ of full professors were women, $20 \%$ of associate professors, and $38 \%$ of assistant professors. (The instructor/lecturer category is too small to evaluate.)

Again there is a situation of earlier dramatic improvement, falling short of parity. The increase from $5 \%$ to $12 \%$ in the proportion of full professors who are women is a major gain, but women continued to be less well represented in the higher ranks. This situation may be a consequence of the failure to promote women at the same rate as men, or a result of the younger professional age of women compared to men Ph.D.s (ASA 1984), or both.

These data do not reveal whether women once hired were less likely to be promoted than men and why. Women are now 38\% of assistant professors; if discriminatory practices have ceased, we expect to see women moving up through the ranks to parity with men in future years. If subtle discrimination remains, or other barriers such as women's dual responsibility for work and family are serious impediments (Hewlitt 1986), then disparities in rank by gender will continue to exist. National data indicate gender discrepancies in rank within each cohort, but the differences lessen over time (ASA 1984).

\section{Departmental Chairpersonships}

If professional status is viewed in terms of hierarchical advancement, the movement of women into administrative leadership needs to be assessed. Table 4 presents data on women chairpersons of sociology departments in universities, colleges, and four-year technical schools, and junior and community colleges. In 1984, women held 16\% of all chair positions, slightly more than in 1980.

Comparison of the proportion of women chairs to the proportion of women full-time faculty (19\%) suggests a relatively small gap between parity and reality. At the university level, by definition the only category to have graduate programs and so be comparable with our rank data, women hold $13 \%$ of chairs, while they hold $15 \%$ of associate and professor positions. This is, all in all, not such a bad record. 
Table 4. The Distribution of Chairpersons of Midwest Departments of Sociology by Type of Institution and by Gender. 1980 and 1984

\begin{tabular}{|c|c|c|c|c|c|c|c|c|}
\hline & \multicolumn{4}{|c|}{1980} & \multicolumn{4}{|c|}{1984} \\
\hline & \multicolumn{2}{|c|}{ Women } & \multirow[b]{2}{*}{ Unknown } & \multirow[b]{2}{*}{ Total } & \multicolumn{2}{|c|}{ Women } & \multirow[b]{2}{*}{ Unknown } & \multirow[b]{2}{*}{ Tota } \\
\hline & $N$ & $\begin{array}{c}\text { Percentage of } \\
\text { All Faculty }\end{array}$ & & & $N$ & $\begin{array}{l}\text { Percentage of } \\
\text { All Faculty }\end{array}$ & & \\
\hline Universities & 4 & 9 & 1 & 44 & 5 & 13 & 3 & 39 \\
\hline Colleges/Tech & 27 & 15 & 10 & 186 & 31 & 17 & 10 & 185 \\
\hline Junior colleges & 16 & 16 & 12 & 101 & 15 & 16 & 17 & 97 \\
\hline All chairs & 47 & 14 & 23 & 331 & 51 & 16 & 11 & 321 \\
\hline
\end{tabular}

We also find that in 1984, 25\% of women chairs served at junior and community colleges, $61 \%$ at four-year colleges, and $10 \%$ at universities. These percentages rather closely approximate the male distribution for the first two categories $(28 \%, 58 \%)$, although males are more likely $(14 \%)$ to be serving as chair at the university level.

\section{Participation in the Discipline}

In this section the participation of women on the program of the MSS annual meeting and in leadership roles in the Midwest Sociological Society will be assessed.

\section{MSS Leadership and Committee Positions}

We follow Thompson et al. (1980) in using the MSS presidency, state directorships, and committees to examine women's participation in professional association leadership.

The first woman MSS president, Ruth Shonle Cavan, took office in 1960. Caroline Rose was president in 1973-1974, beginning a period in which the presidency was frequently held by women: Helena Lopata, 1975-1976; Joan Huber, 1979-1980; and Ethel Shanas, 1980-1981. Although no woman served as president from 1981-1982 through the 1986 term, Kathleen Crittenden is the 1987-1988 president. $^{6}$ Women have been extremely visible as presidents of MSS in the last decade and a half.

Women were among the nine state directors of the MSS board in each of the years studied except 1970-1971. As Table 5 indicates, there was considerable fluctuation in numbers and thus no apparent trend emerged. In recent years there has been strong representation of women, with at least three women directors each year from 1981 onward.

Participation of women on MSS committees has been substantial in all years reviewed except 1970 (Table 5). In 1984, women were 38\% of committee members, while they comprised 36\% of MSS membership (Selbyg 1985). Without the Status of Women Committee, women's representation on committees was 33\% in 1984 and 40\% in 1982. In earlier years women had fewer memberships on these other committees; however, they were also a smaller proportion of the membership (23\% in 1979) (J. Huber 1980). ${ }^{7}$ 
Table 5. Representation of Women as MSS State Directors, Committee Chairpersons and Members: 1968-1984*

\begin{tabular}{|c|c|c|c|c|c|c|}
\hline \multirow[b]{2}{*}{ Year } & \multirow{2}{*}{$\frac{\text { State Directors }^{* *}}{N}$} & \multicolumn{2}{|c|}{ Committee Chairpersons } & \multicolumn{3}{|c|}{ Committee Members } \\
\hline & & $\begin{array}{l}\text { Total } \\
\text { Chairs }\end{array}$ & $\begin{array}{c}N \\
\text { Women }\end{array}$ & $\begin{array}{c}\text { Total } \\
\text { Members }\end{array}$ & $\begin{array}{c}N \\
\text { Women }\end{array}$ & $\begin{array}{c}\text { Percentage } \\
\text { Women }\end{array}$ \\
\hline 1968 & - & 6 & 0 & 22 & 5 & 23 \\
\hline 1970 & 1 & 9 & 0 & 34 & 1 & 3 \\
\hline 1972 & 2 & 9 & 1 & 40 & 17 & 42 \\
\hline 1974 & 4 & 13 & 2 & 50 & 14 & 28 \\
\hline 1976 & 2 & 8 & 1 & 37 & 15 & 41 \\
\hline 1978 & 5 & 8 & 1 & 53 & 19 & 36 \\
\hline 1980 & 4 & 8 & 2 & 52 & 21 & 40 \\
\hline 1982 & 3 & 10 & 3 & 63 & 26 & 41 \\
\hline 1984 & 5 & 10 & 5 & 80 & 30 & 38 \\
\hline Total & 26 & 81 & 15 & 431 & 148 & 34 \\
\hline
\end{tabular}

* Membership and Crisis Committees were not included through 1980 since their membership is automatically composed of state directors and past, present, and future presidents, respectively. From 1981 onward we included the membership committee chair, although not the automatically appointed members composing that committee.

** There are nine state directors each year. Number indicates largest number of women representatives in the two-year period (terms overlap).

In the past, women fared less well as committee chairs. Until 1982, women had never held more than two committee chairs in any year, and often fewer, usually one of these chairpersonships was the Status of Women Committee. The situation has changed dramatically in recent years; women held three of the ten committee chairs in 1982 and five in 1984.

\section{MSS Annual Meetings}

Women have increased their participation as chairpersons, presenters of papers, and discussants at MSS annual meetings (Table 6). In 1982, $28 \%$ of session chairs, $24 \%$ of paper presenters, and $26 \%$ of discussants were women. This percentage compares favorably

Table 6. Participation of Women in MSS Sessions: 1968-1982*

\begin{tabular}{|c|c|c|c|c|c|c|}
\hline \multirow[b]{2}{*}{ Year } & \multicolumn{2}{|r|}{ Chair } & \multicolumn{2}{|c|}{ Discussant } & \multicolumn{2}{|c|}{ Presenter } \\
\hline & Total & Percentage Women & Total & Percentage Women & Total & Percentage Women \\
\hline 1968 & 21 & 14 & 13 & 0 & 96 & 15 \\
\hline 1970 & 32 & 6 & 7 & 0 & 121 & 7 \\
\hline 1972 & 46 & 9 & 9 & 11 & 193 & 17 \\
\hline 1974 & 86 & 15 & 68 & 18 & 418 & 20 \\
\hline 1976 & 114 & 22 & 47 & 19 & 440 & 21 \\
\hline 1978 & 61 & 31 & 20 & 25 & 250 & 27 \\
\hline 1980 & 96 & 27 & 40 & 32 & 291 & 33 \\
\hline 1982 & 96 & 28 & 47 & 26 & 432 & 24 \\
\hline
\end{tabular}

* Those who could not be identified by their names as male or female were omitted from calculations. 
with the presence of women on faculties and as members of MSS in 1979, although less favorably with current membership strength. The increase in participation over time suggests increased activity on the part of women and/or increased recognition of their work, research interests, and organizing ability.

In part the increased presence of women on the program is due to the inclusion from 1975 onward of sessions organized by Midwest Sociologists for Women in Society. Although men are also presenters, these sessions undoubtedly provide opportunities for women whose research interests are women and women's issues. The expansion of such opportunities is, after all, the point. However, women also played a very active role in the rest of the 1982 MSS program as $24 \%$ of session chairs, $21 \%$ of presenters, and $21 \%$ of discussants.

\section{Discussion}

The data presented on the employment and professional participation of women academic sociologists in the Midwest indicate rapid improvement of women's employment status during the 1970s in terms of sociology department academic employment, full- time faculty positions, rank, and presence in Ph.D. programs, but slowed progress during the 1980s. Women have made gains in professional participation throughout this period.

We turn first to employment status as the most problematic area and one that can be linked with issues of gender and racial equality in other occupations. Our data present interpretive problems typical of efforts to identify discrimination and generate remedial public policy through the use of group data. As is common in public policy research, the data available are not shaped by the problem, but by the recording system of the institution.

Using the available data on sociology graduate program employment, we argue that a comparison of this data with the proportion of women Ph.D.s in sociology points to the conclusion that women have not yet attained equal employment status.

\section{Statistical Parity as a Standard of Equality}

We define statistical parity as the appropriate measure of equality. If women are not employed at all levels in proportion to their availability (27\%) in the Ph.D. pool, we infer that a problem exists that should be remedied. While our data cannot establish discrimination, that is, action taken by employing departments or universities to exclude women from hiring or promotion, they do indicate inequity, a less favorable position of women in the system. This continues to be the case despite substantial progress through the seventies.

This perspective can be challenged in terms of technical issues in the interpretation of data, but differences in conclusion-drawing more likely reflect disputes over the meaning of equality between the sexes. Statistical parity as a standard of equality represents an assimilationist model of sexual equality (Rossi 1972), in which women are expected to have the same degree of professional involvement and accomplishment that men have had. This perspective has been attacked from several directions. Conservatives (e.g., Sowell 1984) argue that employment of women at lower statuses and salaries does not indicate discrimination, but rather choices set by women's desire to place family interests 
first. Some feminists, as well, claim that women possess a distinctive culture that limits individual ambition to take the needs of others into account (Gilligan 1982). According to Stacey (1986), "Contemporary feminist visions are... characterized by unresolved tension between advocating androgyny and celebrating traditionally female, and especially maternal, values" (p. 226).

The recent Sears case (Equal Employment Opportunity Commission v. Sears, 1986) focused this debate. In this case, a complaint of discrimination was based on statistical data showing gender differences in employment in the well-paying commission sales positions. Respected women historians serving as expert witnesses argued for each side. For the defense, it was claimed that historical differences in men's and women's employment patterns reflect women's preference for noncompetitive work that does not interfere with family commitments; while for the plaintiffs, it was asserted that these data indicate a discriminatory lack of choice in a society that has socialized men and women differently and provided them with different opportunities: Women have taken advantage of nontraditional employment opportunities when they have been available (Freedman 1986; Sternhell 1986; see also Cohn 1985). The issue was and is: Does statistical disparity in employment represent inequity or choice?

In the scope of this article, we cannot settle the broad controversy over the status of women in society, goals of the women's movement, or the reconciliation of work and family for women and men. We simply call attention to these issues to acknowledge that our data have no single interpretation, but are given meaning in the context of this value conflict.

Professional sociological associations do accept the assimilationist premise that parity of women with men in employment is the standard of equality and a desirable goal (e.g., ASA 1984). Attainment of the Ph.D. is assumed to represent a desire and commitment to work. The hypothesis that women's family commitments explain their lower employment status is not easily supported by data on academic women. According to a National Research Council study, "neither marital status nor presence of children accounted for women's lower rate of promotion to tenure" (ASA 1984). A study of publication rates among social work academics found the presence of preschool children positively associated with publication, with no evidence of gender difference in motivation to do research (Fox and Faver 1985).

\section{Structural Barriers to Equality in Employment}

Efforts to improve the status of women today face some hidden barriers to advancement rather than overt discrimination. Women may be differentially evaluated in subtle ways (see Gappa and Uehling 1979; Goldberg 1968; Pheterson et al. 1971).

More important, structural limits to the employment of sociologists are a major barrier to the attainment of equal employment status by women. Equal education opportunity legislation and affirmation action programs, as well as changing attitudes toward women and work, opened the academy to women in the 1970s. But the declining number of new jobs in sociology has limited career opportunity. Massive hiring during the expansive 1960s and early 1970s locked in a substantial number of positions until the retirement of their (disproportionately male) incumbents. The slowed pace of gain in women's employment in full-time positions compared to more rapid progress in the 1970s is surely connected to the end of growth. Our data indicate that both full-time positions, and total positions peaked in the late 1970s (Table 1). 
If discrimination no longer occurs, the increased inclusion of women that began in the 1970s should be followed by attainment of tenure and rank for those women. But structural factors restricting entry into the field have cut short fulfillment of this trend toward the equality of women.

To what extent does this situation demand a remedy? Do our data, which indicate that women are not currently employed in proportion to their availability, suggest an actionable inequity absent direct discrimination? Here, again, values are at issue, not technical interpretations of data.

The question of remedy for past discrimination is widely debated today. Compensatory hiring and promotion policies have received mixed reviews in the courts depending on whether they require targeted hiring, promotions, or layoffs; whether they are a part of a consent decree or a union contract; whether there is direct evidence of discriminatory past practice or simply statistical disparity in employment; whether women were underrepresented or completely excluded from employment (Johnson v. Transportation Agency of Santa Clara County, 1987; Taylor 1986a, b). Courts appeared for a while to be receptive to the argument that statistical disparity in the absence of proof of discrimination in specific cases was not convincing (American Federation of States, County, and Municipal Employees v. Washington, 1985; Equal Employment Opportunity Commission v. Sears, 1987). But the recent Johnson case (Johnson v. Transportation Agency of Santa Clara County, 1987) dramatically affirmed the adequacy of statistical data standing alone as evidence of remediable discrimination.

The American Sociological Association recently adopted a compensatory policy analogous to that of other public and private employers. It recommends specific targets: $25 \%$ women would achieve tenured positions by 1990 and "approximately half of Assistant Professor appointments between now and 1990 would go to women" (ASA 1984, p. 7). Publication of the ASA guidelines has apparently not generated much controversy, but neither have these guidelines been formally accepted by sociologists or acted on by departments as far as we are aware.

\section{Professional Participation: A Success Story}

Compensatory efforts in the area of professional participation have been much more common and, judging by our data, appear to have been successful. One difference between the two areas may be that there is a single locus of professional participation, while employment decisions are dispersed. Integration of women into MSS activities is highly visible and subject to control by leaders, both men and women, who are fully committed to this end. Comparison with the American Public Health Association, which has a more decentralized structure, is instructive. Researchers investigating the exclusion of women from organizational leadership noted that a structure of strong, autonomous (and sexsegregated) sectional units made it difficult for women to become generally known and tapped for leadership (Yokopeonic et al. 1975). Mobilization for change would obviously be more difficult in a decentralized system.

Also, the number of organizational positions is more elastic than is employment at the moment. Allocation of the latter scarce resource not only engenders competition over individual positions, but presents more potential for struggle over allocation systems themselves (Calabresi and Bobbitt 1978) should compensatory hiring be seriously considered. 


\section{Conclusion}

Our greatest attention should now be directed to employment status. Fortunately, the strong gains made by women in the 1970s do not appear to have been eroded by financial pressures on the universities. Although parity has not been attained, improvement has occurred. Should the increasing presence of women in each cohort evolve into parity with men, the issue of inequity will have been resolved. If parity continues to elude women despite evidence that women sociologists have aspirations identical to men, the sociology profession must address itself vigorously to the task of ascertaining causes and devising remedies that bring women to full equality.

\section{Acknowledgments}

An earlier version of this article was presented at the annual meeting of the Midwest Sociological Society, St. Louis, Missouri, April 10, 1985.

\section{Notes}

1. The Midwest region includes Illinois, Iowa, Kansas, Minnesota, Missouri, Nebraska, North Dakota, South Dakota, and Wisconsin.

2. Data prior to 1980 are the work of Thompson, et al (1980). These reports are the product of an ongoing monitoring project of the MSS committee on the Status of Women in the Profession.

3. In 1985 there were 32 graduate programs: 16 M.A. and 16 Ph.D. programs. Comparisons over time are flawed by fluctuations in program status over the years. Because detailed tracing of changes in graduate programs was beyond the scope of this report, we make the working assumption that termination of programs does not differentially affect men and women.

4. Specialists in social statistics, criminology and criminal justice, regional and urban planning were excluded from this National Research Council survey of doctorate holders. The survey includes all women Ph.D.s, while our employment data are based on graduate programs only.

5. One possible benign explanation is that graduate students completing their degrees may take part-time employment as a convenience. The large percentage of women could represent a normal transition for a heavily female group. (Women in fact, received 38\% of Ph.D.s in 1981 [ASA 1984].) We argue that dissertation-stage students work as part-time faculty at other colleges, while remaining teaching assistants at their graduate institutions (Gappa 1984). An AAUP survey indicates that while women were $38.7 \%$ of all part-timers, they comprised $52.6 \%$ of the "hopeful full-timer" category (Tuckman 1978, cited in Gappa 1984).

6. MSS terms of office were converted to the calendar year between 1982 and 1983.

7. Data for most other years are not easily obtainable.

\section{References}

Abel, E. 1984. Terminal Degrees: The Job Crisis in Higher Education. New York: Praeger.

American Federation of State, County, and Municipal Employees v. State of Washington. 770 F.2d 1401 (9th Cir. 1985). 
American Sociological Association (ASA). 1984. Guidelines for Incorporating Women Faculty into Departments of Sociology during the Eighties. Washington, DC: American Sociological Association.

Calabresi, G., and G.P. Bobbitt. 1978. Tragic Choices. New York: Norton.

Cohn, S. 1985. The Process of Occupational Sex-Typing: The Feminization of Clerical Labor in Great Britain. Philadelphia: Temple University Press.

Equal Employment Opportunity Commission v. Sears, Roebuck, and Co. 628 F. Supp. 1286 (1986).

Fox, M.F., and C.A. Faver. 1985. "Men, Women, and Publication Productivity: Patterns Among Social Work Academics." The Sociological Quarterly 26: 537-549.

Freedman, S.G. 1986. “Of History and Politics: Bitter Feminist Debate.” The New York Times (June 6), p. Bl.

Gappa, J.M., and B.S. Uehling. 1979. Women in Academe: Steps to Greater Equality. Washington, DC: American Association for Higher Education.

Gappa, J.M. 1984. Part-time Faculty: Higher Education at a Crossroads. ASHE-ERIC Higher Education Research Reports, No. 3. Washington, DC: Association for the Study of Higher Education.

Gilligan, Carol. 1982. In a Different Voice: Psychological Theory and Womens' Development. Cambridge, MA: Harvard University Press.

Goldberg, P. 1968. “Are Women Prejudiced Against Women?" Trans-action 5: 28-30.

Griffin, B.S., and C.T. Griffin. 1985. “Dead End Jobs and Affirmative Action.” Paper presented at the Annual Meeting of the Midwest Sociological Society, St. Louis, April 10-13.

Hacker, A. 1986. “Women at Work.” The New York Review of Books August 14: 26-32.

Hartung, B. 1985. "Labor Market Segmentation and Academic Underemployment." Paper presented at the Annual Meeting of the Midwest Sociological Society, St. Louis, April 10-13.

Hess, E. 1984. Personal communication.

Hewitt, S.A. 1986. A Lesser Life: The Myth of Women's Liberation in America. New York: Morrow.

Huber, B. 1982. “Sociology Ph.D. Production Declines in the Late 70s." ASA Footnotes 10 (Feb.): 2.

Huber, J. 1980. Personal communication cited in Thompson et al., 1980.

Johnson v. Transportation Agency, Santa Clara County, California. 748 F.2d 1308 (9th Cir. 1987).

Lindgren, J.R., P.T. Ota, P.A. Zirkel, and N. Van Giesen. 1984. Sex Discrimination Law in Higher Education: The Lessons of the Past Decade. ASHE-ERIC Higher Education Research Report, No. 4. Washington, DC: Association for the Study of Higher Education.

Lynn v. Regents of the University of California. 656 F. 2d 1337 (9th Cir. 1981), cert. denied, 103 S.Ct. 53 (1981, 1982).

Pheterson, G.I., S.B. Kiesler, and P.A. Goldberg. 1971. “Evaluation of the Performance of Women as a Function of Their Sex, Achievement, and Personal History." Journal of Personality and Social Psychology 19: 114-118.

Rohter, L. 1987. “Women Gain Degrees, But Not Tenure.” New York Times (January 4), p. E9.

Rossi, A.S. 1972. "Sex Equality: The Beginnings of Ideology." Pp. 344-353 in Toward a Sociology of Women, edited by Constantina Safilios-Rothschild. Lexington, MA: Xerox.

Selbyg, A. 1985. Personal communication.

Smith v. University of North Carolina. 632 F. 2d 316 (4th Cir. 1980).

Sowell, T. 1984. Civil Rights. New York: Morrow.

Stacey, J. 1986. “Are Feminists Afraid to Leave Home? The Challenge of Conservative Pro- family Feminism." Pp. 208-237 in What Is Feminism/ A Re-examination, edited by Juliet Mitchell and Ann Oakley. New York: Pantheon.

Sternhell, C. 1986. "Life in the Mainstream: What Happens When Feminists Turn Up on Both Sides of the Courtroom?" MS. XIV (July): 48-51, 86-91. 
Szafran, R.F. 1984. Universities and Women Faculty: Why Some Organizations Discriminate More than Others. New York: Praeger.

Taylor, S., Jr. 1986a. “Affirmative Action Upheld....” The New York Tines (March 3), p. 1. . 1986b. "Justice Department Asks Supreme Court to End Job Plan Favoring Women." The New York Times (August 29), p. 1.

Thompson, M.E., S.E. Wright, J. Wittner, V. Fish. 1980. “Women Sociologists in the Midwest: A Status Report." The Sociological Quarterly 21: 623-633.

Tuckman, H.P. 1978. "Who is Part-time in Academe?" AA UP Bulletin 66: 71-86.

Williams, P.R. 1982. “Minorities and Women in Sociology: An Update." ASA Footnotes (Dec.) 6-8.

Women's Rights Law Reporter (Eds.). 1985. “Case Update: American Federation of State, County, and Municipal Employees v. Washington 770 F2d 1401 (9th Circ.), 1985." Women's Rights Law Reporter 8: 209-210.

Yokopenic, P.A., L.B. Bourgue, and D. Brogan. 1975. "Professional Communication Networks: A Case Study of Women in the American Public Health Association." Social Problems 20: 493-509. 